\title{
Women as agents of glocalization in the Orthodox Church of Finland
}

\section{Kupari, Helena}

Fordham University Press

2021

Kupari , H \& Tiaynen-Qadir , T 2021, Women as agents of glocalization in the Orthodox Church of Finland . in I Merdjanova (ed.), Women and Religiosity in Orthodox Christianity . Fordham University Press, New York, pp. 206-240 .

http://hdl.handle.net/10138/338542

unspecified

acceptedVersion

Downloaded from Helda, University of Helsinki institutional repository.

This is an electronic reprint of the original article.

This reprint may differ from the original in pagination and typographic detail.

Please cite the original version. 
Women as Agents of Glocalization in the Orthodox Church of Finland Helena Kupari and Tatiana Tiaynen-Qadir

In: Women and Religiosity in Orthodox Christianity, edited by Ina Merdjanova, 206-240. New York: Fordham University Press, 2021.

\section{Introduction}

Most contemporary scholarly accounts divide Orthodox Christian churches across the world into national churches in the Eastern European heartlands and diasporic churches in the West. Using this categorization, they argue that the Orthodox religion functions as a cultural or national marker that implies belonging to a certain ethnic or national group. Such categorizations are analytically suitable for exploring many social aspects of religion. Yet they tend to brush aside the cross-cutting, transnational, and noncognitive aspects of lived religion that cannot be easily captured by this division. The Orthodox Church of Finland (OCF) is an interesting case as it can be seen both as a national minority church in a culturally dominant Lutheran context and as a growing site of transnational, multicultural, and multilingual interaction. Thus, we suggest that Finnish Orthodoxy is better conceived of as a glocal religion in the making, in which relations and tensions between different cultural and national aspects (Finnish, Karelian, Russian, Byzantine) fuel a perpetual process of glocal becoming. In this chapter, we argue that Orthodox women are important agents in this process of glocalization.

More specifically, we focus on the life stories and experiences of Orthodox women of two generations: older Karelian women, "cradle" Orthodox, who along with their families were dislocated from the Orthodox-dominated easternmost part of Finland during World War II; and younger women from Finnish, Karelian, Russian, and Ukrainian backgrounds, some of whom are either "returnees" or converts to Orthodoxy. We demonstrate how women from different backgrounds actively strive to make Finnish Orthodoxy their spiritual and social home. Furthermore, we argue that their practices and agentic capabilities feed into the glocal making of Finnish Orthodoxy. We illustrate this process by focusing on women's agency as manifested in (1) experiences of the Divine Liturgy, (2) family making as mothers and grandmothers, and (3) participation in parish life. In doing so, we contribute to recent critical scholarship on gender and religion, which deconstructs the understanding of agency as penetrative, action driven, and limited to the social power/resistance frame. In contrast, our engagement with vernacular and material religion allows for the conceptualization of women's agency as multifaceted and inclusive of women's sensorial and interpretative religious experiences.

Our analysis is based on two sets of qualitative data. The first set of data, on the older generation, was gathered by Helena Kupari between 2007 and 2008. It consists primarily of interviews with twenty-four Orthodox Christian women of Karelian ancestry. In addition, Kupari also conducted small-scale ethnographic fieldwork at an OCF parish in a southern Finnish city, participating in parish activities frequented by elderly parishioners. At the time of the interviews, Kupari's interlocutors were on average seventy-five years old. In compliance with a more general trend among Finnish Orthodox women of their generation, a great majority of them had married Lutheran men, and their children had been baptized into Lutheranism. ${ }^{1}$ At the time when the data was gathered they mostly lived alone, as widows or divorcées. The second set of data, on the younger generation of women, was gathered by Tatiana Tiaynen-Qadir between 2014 and 2016 in a vibrant and multicultural OCF parish located in western 
Finland. Tiaynen-Qadir's fieldwork included participant and nonparticipant observation in informal gatherings, clubs, church services, and choir practices. In this chapter, she draws on ethnographic interviews with twenty women, aged thirty to fifty-three, from Finnish, Karelian, Russian, and Ukrainian backgrounds. The interviews were conducted in the Finnish and Russian languages. Most of the interviewees were teachers, university lecturers, accountants, researchers, and doctors and had university degrees.

\section{Orthodox Christianity in Finland}

The more systematic Christianization of the area now known as Finland began around the twelfth and thirteenth centuries. In the sixteenth century, the Protestant Reformation was carried out in the area by the Swedish crown. Some two and a half centuries later, Sweden lost Finland to the expanding Russian Empire. The country finally gained independence in the aftermath of the 1917 revolutions in Russia. At that point, Finland was firmly Lutheran dominated, with 98 percent of the population belonging to the Evangelical Lutheran Church of Finland. A hundred years later, in 2017, 71 percent of Finns were members of the Lutheran Church. ${ }^{2}$

Orthodox Christianity has had a presence in the southeastern parts of today's Finland ever since the area was first Christianized. The region of Karelia, which occupies an intermediate position between Finland and Russia, was introduced to Christianity in its Eastern form by Novgorodians, who had adopted this religion from the Byzantines through Kiev at the end of the tenth century. ${ }^{3}$ However, over the course of time Western Christianity became dominant in most of the parts of Karelia that were subjected to Swedish rule. During the nineteenth century, when Finland was a grand duchy of the Russian Empire, the significance of the Orthodox Church increased. After Finland gained independence, the OCF separated from the Russian Orthodox Church, receiving autonomous status under the Patriarchate of Constantinople. ${ }^{4}$

The history of Finnish Orthodoxy embraces various migrations, dislocations, and other enforced and voluntary moves of numerous peoples: Karelians, Russians, and others. ${ }^{5}$ Ever since the rise of nationalist discourses in Finland and Russia in the nineteenth century, the community has struggled with its selfimage, striving to reconcile (alleged) tensions between Karelian, Russian, and Finnish Orthodox identities. The first half of the twentieth century, for example, was marked by a process of nationalization or Finnicization. Especially after Finland gained independence, the OCF took active measures to disassociate Finnish Orthodoxy from its Russian heritage. ${ }^{6}$ At this time, the Orthodox heartlands of Finland were located in Karelia. In World War II, however, Finland lost most of its Karelian territories to the Soviet Union. Over four hundred thousand Finnish Karelians became internally displaced people. About 55,000 of them were Orthodox Christians, constituting two-thirds of the Finnish Orthodox population. ${ }^{7}$

In post-World War II Finland, the public image of the OCF suffered, given its association with "Russianness." However, as the postwar survival mentality gradually gave way, Finnish society became more tolerant of difference. The popularity of the OCF started to grow in the 1970s. Finnish intellectuals, influenced by the "Romantic movement," became interested in the Byzantine art of icons and church music, which over time enhanced the oriental and exotic image of Orthodoxy in Finland. Budding religious pluralism in the form of, for example, new religious movements also reflected positively on the 
status of Orthodox Christianity as an "indigenous" minority religion. ${ }^{8}$ Simultaneously, growing urbanization and internal migration catalyzed a newfound interest in regional cultures, including Karelian traditions.

In present-day Finland, any attentive observer will quickly take note of the visibility of the OCF and Orthodox cultural and aesthetic influences in various parts of the country. The presence of Orthodoxy is especially surprising when compared to statistics regarding church membership. At the end of 2017, 1 percent of the population of Finland belonged to the Orthodox Church. ${ }^{9}$ This amounts to approximately sixty thousand people in a total population of over five million. However, since the OCF enjoys a similar privileged legal status as the Lutheran Church, it is guaranteed a role in many public events and official functions. Generally speaking, the two "folk churches" of the country enjoy good ecumenical relationships and interact closely, harboring little resentment toward each other. ${ }^{10}$ On an individual level, conversions from Lutheranism to Orthodoxy and vice versa take place. Many Orthodox are familiar with and enjoy aspects of Lutheranism, such as Lutheran hymns. Similarly, Lutherans can be drawn to elements of Orthodoxy without feeling any urge to change their denominational affiliation. Overall, many contemporary Finns with wide-ranging beliefs keep Orthodox icons in their homes, attend iconpainting courses, appreciate Orthodox church architecture, follow the Orthodox Easter Vigil from television, and enjoy Orthodox choir singing.

From the 1990s onward, the OCF started to undergo a process of transnationalization, mainly attributable to an influx of migrants from Eastern European countries. Between 1990 and 2009, the share of foreign-born church members increased from 3 to 11 percent. ${ }^{11}$ However, this does not include those practitioners who are not officially registered but share some form of commitment to Orthodoxy. Most likely, a large number of individuals among the Russian-language minority of Finland (the largest migrant minority of the country, roughly estimated at 77,000$)^{12}$ consider themselves Orthodox but have not officially joined the OCF. The Church has taken into consideration the increasing heterogeneity of its members. Many parishes, especially urban ones, celebrate the Liturgy in different languages and provide various other activities and services for their migrant members. ${ }^{13}$ Among the OCF's clergy and employees are individuals of diverse national and ethnic backgrounds (e.g., Russian, Greek, Polish, and Sámi).

What differentiates the OCF from most Orthodox churches is that it is a national church operating in a Western European society dominated by Protestant Christianity. Based on many conventional measures, Finland is among the most advanced societies globally when it comes to gender equality. According to World Values Survey data, the great majority of Finns consider the rights of women as a cornerstone of democracy and support women's equal participation in society, including the job market, higher education, and political life. ${ }^{14}$ This does not mean, however, that the society has similar expectations of both genders. For instance, Finnish women continue to shoulder more responsibility for taking care of the home and family compared to men.

In the OCF, women are allowed to conduct the choir at church services, and the majority of cantors employed by the Church are, in fact, women. The same also holds true for teachers of Orthodox religious education. ${ }^{15}$ Women can and often do act as readers in religious services. Moreover, another noteworthy feature of contemporary Finnish Orthodoxy is the central role of women as iconographers. At present, over 90 percent of the members of the Association of Finnish Icon Painters are women. ${ }^{16}$ More generally speaking, at the end of 2017, 56 percent of all members of the Church were women. ${ }^{17}$ 
The over-representation of women in the OCF is in line with nationwide survey material, which shows that there are clear gender differences in contemporary Finns' attachment to religion. More women than men belong to different Christian communities, consider religion an important aspect of their lives, believe in basic Christian teachings, and are active in both their public and private religious practice. ${ }^{18}$

Since the 1960s, the Lutheran Church has, from time to time, received public criticism for its conservative stance regarding questions of equality. ${ }^{19}$ The most recent discussions have focused on the rights of sexual minorities. Marriages between same-sex couples have been legalized in Finland, but the Lutheran Church has not officially condoned such marriages-unlike its counterparts in other Nordic countries. Meanwhile, the views and policies of the OCF on the same questions have not received similar attention. The OCF does not recognize female ordination or marriages between same-sex couples, yet this position has for the most part gone unchallenged in the wider society. In contemporary Finland, minority confessions and religions are often not expected to comply with societal norms to the same extent as the Lutheran Church.

In its official statements, the OCF has presented itself as a unanimous body not influenced by currents of societal discourse. However, within the Orthodox community debates regarding the correct interpretation of the Bible and the significance and application of Orthodox canon law in matters of gender equality and sexual ethics do surface from time to time. ${ }^{20}$ Both Orthodox clergy and active lay people take part in negotiations concerning the OCF's proper place in the increasingly pluralistic and culturally liberal Finnish society, for example, in Orthodox media. ${ }^{21}$

The theologian Elina Vuola's recent study, based on interview material, suggests that Finnish Orthodox women hold a wide variety of views regarding the status of women in Orthodoxy. Some of Vuola's interlocutors compared OCF teachings and policies with those of the Lutheran Church, concluding that Orthodoxy discriminates against women. Many, however, emphasized that the presence of a feminine imaginary as well as concrete women - such as the Mother of God and female saints -is much more prevalent in Orthodoxy than in Lutheranism. Of these two confessions, they thus considered Orthodoxy to be more inclusive and respectful of femininity. ${ }^{22}$ This variance of opinion illustrates the complex dynamics involved in women's experiences of equality. Overall, Vuola's empirical findings are in line with recent advances in postcolonial feminism stressing the need for more nuanced investigations of religion and gender, investigations that refrain from posing Protestantism as an ideal type against which the "progress" of other religions is measured. ${ }^{23}$

In our contribution, we do not focus on women's opinions concerning gender-related issues in Orthodoxy. Rather, our goal is to explore how Orthodox women of different ages and backgrounds express their religious and gendered identity, how they negotiate for a space to address their spiritual and social needs in the context of the OCF, and how their religious observance and related activities contribute to the making of Orthodoxy in Finland a glocal religion. To achieve this, we draw on theoretical discussions related to glocalization, vernacular and material religion, and gendered religious agency.

\section{Glocalization, Women's Agency, and the Feel of Home}


Theories of glocalization address the multidirectional interaction between homogenizing and diversifying tendencies in a culture. ${ }^{24}$ The term glocalization refers to the merging of global and local elements resulting in the creation of glocal cultural forms ${ }^{25}$ Religion too, as Victor Roudometof's account of Orthodox Christianity illustrates, can be understood through the lens of historical glocalization, involving a fusion between religious universalism and local particularism. ${ }^{26}$ In this chapter, we approach Orthodox Christianity as a dynamic religious tradition that has the ability to blend with different social, cultural, and political contexts and perpetually transform itself. ${ }^{27}$ Nationalization as an outgrowth of the rise of modern nation-states and transnationalization as an outgrowth of increased migration and multiculturalism are the two major forces that shape the glocalization of Orthodox Christianity today. Nevertheless, there is still little understanding of how glocalization works at the grassroots level of different Orthodox churches and communities and what the role of women is in this process. To shed light on these issues, we expand the standard glocalization framework by incorporating insights from other strands of theorizing.

Most of our interlocutors share personal histories of translocal or transnational moves: Whereas the older Karelian women were forced to relocate from their childhood homes, many of our younger interlocutors moved to Finland from elsewhere. To capture the significance of these histories in the women's present-day religious lives, we apply transnational anthropology, which challenges methodological nationalism and emphasizes multisited lives and senses of belonging. ${ }^{28}$ The starting point of our discussion is that the women's engagements with religion arise from and reflect their transnational subjectivities. Simultaneously, we acknowledge that national senses of belonging also play a role in their religiosity.

Transnational subjectivity is a notion that "makes mobility a historical trajectory of one's own, always connecting to where one is located but simultaneously keeping oneself solidly anchored in one's own story and oneself." ${ }^{29}$ In our discussion, we illustrate how transnational subjectivities are not only cognitively but also sensually constituted, through embodied memories of past homes and relocations. ${ }^{30}$ Moreover, we also suggest that this notion can be applied to study even those who move translocallylike in the case of the Karelian women, whose relocation (at least from their perspective) took place within a single national site.

At present, agency constitutes a focal concept through which scholars examine gender and religion, particularly women's religion. A burgeoning body of research discusses women's religious observance, artistry, and creativity as agentic activity and criticizes the use of secular and liberalist conceptions of agency to assess religious women's actions. ${ }^{31}$ Yet mainstream feminist scholarship has been slow to appreciate women's religious lives and continues to represent conservatively religious women as unaware victims who have internalized their own oppression within the grids of patriarchal culture. ${ }^{32}$

In our contribution, we focus on how our interlocutors' agency is realized through their virtuoso religiosity, that is to say, their endeavor to abide by the demands of the Orthodox faith - as they understand them. ${ }^{33}$ Furthermore, we understand the women's actions to embody and evince several modalities of agency. Their agency certainly manifests in how they strive to influence the social world they inhabit and manage social relations in different arenas of their life, a project embedded in a wider web of power relations with both enabling and constraining elements. However, in seeking to uncouple the notion of agency from discussions of power and resistance, we mostly prioritize other aspects of their agency. 
In line with recent discussions concerning vernacular religion, which proceed from the premise that people's religiosity necessarily involves a personal, creative, and artistic component, we emphasize our interlocutors' agency in their experiential, interpretative, and inventive engagements with Orthodoxy. ${ }^{34}$ Moreover, drawing from theoretical advances in the study of material religion, we pay special attention to embodied and embedded practices of religion-including sensations, feelings, the unspoken, and the body as the matrix and medium of human experiences. ${ }^{35}$ Thus, we also locate the women's agency in their contemplative practices of Liturgy, sensorial and corporeal experiences of religion, and in their nurturing and care-giving acts. All of these modalities of agency are pertinent to our interlocutors' glocal making of religion, in that they are integral to the women's capacity to create and sustain homelike spaces. Such a multifaceted agency serves both social ends and the goals of inner spirituality.

Finally, we use the notion of home as an emic term, applied by our interlocutors, and as a flexible analytical construct that allows us to capture the women's sensations, discourses, memories, and practices related to their efforts and longing to create a home for themselves and their loved ones. The desire for being or feeling "at home" is what underpins people's agency in constructing their literal, imagined, and spiritual homes. This is a dynamic, ongoing endeavor that evolves around how "one feels or one might fail to feel," including the entire spectrum of sensations, ranging from existential security and serenity to despair and fragility. ${ }^{36}$ Religious practices, as practices of dwelling, contribute in this process. They can be employed by people to position themselves in the physical and metaphysical universe, to inhabit a concrete space and social location, to define borders and grow roots: to make homes. ${ }^{37}$ The use of the plural is important here, as we individuals can simultaneously feel a homelike connection to several places, abodes, and communities.

\section{Liturgy as Glocal Homemaking}

In this section, we focus on the Divine Liturgy (Jumalallinen liturgia in Finnish, Bozhestvennaya liturgiya in Russian), a church service of the Byzantine rite that Orthodox theologians see as a core sacrament, the "heart and soul" of Orthopraxis. The Liturgy signifies a ritualistic mystical remembrance of the life, crucifixion, death, and resurrection of Christ. The quintessence of the service is in partaking in the Holy Communion (the Eucharist), in which faithful receive bread soaked in wine, mixed with warm water, "transubstantiated" into the body and blood of Christ. ${ }^{38}$ As a "synthesis of arts," the Liturgy is a "musical drama on the aesthetic plane," which also includes the arts of burning candles and incense, choral singing, icons, priestly conduct, and prayers. ${ }^{39}$

Irrespective of different ages and cultural and linguistic backgrounds, the narratives of our interlocutors often converged in the importance they placed on participation in the Liturgy. In her previous research, Tatiana Tiaynen-Qadir has illustrated that in its structure and religious aesthetics, the Liturgy in the OCF can be conceived of as a glocal space that combines Finnish, Russian, Karelian, and Byzantine elements. ${ }^{40}$ Therefore, individuals from different backgrounds may sensually and cognitively connect to the Liturgy, generating a feeling of "being at home." In this section, we expand this argument by suggesting that women exhibit artistry and agency in their engagements with the Liturgy as glocal homemaking. In this case, women's agency is often contemplative, sensual, and interior. Yet this agency is also highly dynamic, as it allows for the participation in the Liturgy as "movement within the constitution of home." ${ }^{\prime 1}$ 
The transnational and translocal trajectories of our interlocutors manifested in their different experiences of the Liturgy and influenced how they developed a connection to it through their "homes," literal and imagined. For many Karelian women of the older generation, participation in the Liturgy meant connecting with their childhood homes and communities in Karelia. This land now only exists in their minds and hearts and can sometimes be sensually and bodily remembered through the Liturgy. Our interlocutor Raili, for instance, recollected how every Sunday morning her grandmother used to take her to the Liturgy:

[As a child, the Liturgy] sometimes felt long. But somehow, what stuck with me was I guess the scent of incense. When I go [to church], I find the scent of incense just wonderful. And it brings a wonderful feeling. Nowadays, always when I smell the scent of incense, I think of my childhood, whether sitting or kneeling [at church], well, not sitting, my grandmother would not allow that. You could not sit there. ${ }^{42}$

Many women's narratives also pointed to the continued importance of bodily conduct during the Liturgy, something that they had originally learned during their childhood years: standing still, kneeling, bowing, going forward to light candles, kissing the icons, and making the sign of the cross repeatedly. As Raili's account illustrates, sitting during services was not considered proper behavior. Although standing during services may constitute strenuous physical exercise for those with ailing health (and chairs and benches are available for those in need), the women still preferred to stand. Some explained that this way of "revering God" had been ingrained in their bodies since childhood.

In many ways, the Liturgy thus enabled the multisited and multitemporal presence of the older Karelian women. Through the Liturgy, they maintained a connection to the Karelia of their childhood, their imagined homeland associated with existential security and comforting routine. A longing for and wish to recapture that home were important parts of their sense of belonging and partaking in the Liturgy. The glocal nature of the OCF, its continued incorporation of Karelian elements-including the commemoration of Karelian saints, the use of Karelian terms and the inclusion of certain hymns in the Karelian language in some church services, the presence of icons and other sacred objects evacuated from Karelia in churches, the writing of new Karelian-style icons, and the use of Karelian-style elements and motifs in chapel architecture-facilitated this feeling.

Yet the result was never quite able to recreate the women's original experiences, as is the case with all nostalgic remembering. The presence of Karelia remained too weak. As Martta, for example, noted: "In the olden days, even priests spoke partly in [the Karelian] dialect, sometimes even in church. It felt so soft and cozy and warm to listen. But now it's a different thing altogether, after decades spent here." Moreover, some of the efforts to reintroduce Karelian elements into church life were criticized by women for being "artificial." They were too far removed from what women remembered from their childhood.

Nevertheless, the agency and artistry of these older Karelian women is crucial in making the Liturgy a glocal happening. Their artistry is reflected in how they lived and negotiated their translocal subjectivities and multisited homes through participation in the Liturgy, bringing some aspects of their past to the present. Their agency resided in their individual, contemplative participation in the Liturgy. It was also realized through communal attendance when, as one of the interlocutors put it, "you are one with the others." For the most part, this agency was not purposive or conscious but manifested in the women's presence and natural conduct during the Liturgy, in their bodily actions and postures. Whether wittingly or not, they were an embodiment of a living tradition for many others present during Liturgy. 
For younger participants, these older women may represent the (Karelian) roots of Finnish Orthodoxy or constitute emblems of genuine (grandmother-type) piety. Moreover, for those attendants whose own knowledge of Orthodoxy remains on a more abstract level, such as recent converts, their conduct served as an example of emotional and corporeal participation in the Liturgy.

For many Russian and Ukrainian women who have migrated to Finland as adults, participation in the Liturgy also enabled their multisited presence and connection with their birth homes through sensual engagement. They venerated the same Orthodox icons, immersed in familiar melodies, and recognized similarly decorated church interiors. Many of them emphasized that they enjoyed services in Church Slavonic, which "sounds especially touching probably because it is in Russian." Our interlocutor Anastasiya mentioned that her church in Finland "reminded" her of the church in Russia where she was baptized: "It was great to perceive Finland through the church. As if I lived not in Finland but in this place with this church and these people." Similarly to our older Karelian interlocutors, in their participation these migrant women activated their embodied memories of liturgies celebrated in their home countries, which intensified their sense of "being at home" in the Finnish Liturgy.

However, in contrast to the Karelian women's longing for the Karelia of their memories, which they could not physically reach, many Russian-speaking women maintained multisited lives and transnational families, regularly traveling between family members' abodes. They participated in church services "here" and "there" without thinking much about the national differences in church organization. Rather, their spiritual journey took place within the constitution of their transnational Orthodox home and transnational subjectivities. Our interlocutor Anfisa, for example, described how, while living in Russia, she had "passively" attended services, liking the music, the smell, and the entire "atmosphere." She apprehended Orthodoxy with more "awareness" later after having moved to Finland. She joined the choir and soon became a reader during services in Church Slavonic, usually held once a month. When she visits Russia, she also attends the Liturgy in her home church there.

The glocal nature of the Liturgy in the OCF is enabling in the sense that women from different backgrounds can connect to it sensually and cognitively. Liturgical prayers and texts speak to individuals through the medium of different languages and varying choral arrangements: whether performed in Finnish as a "Slavic melody" or in Ancient Greek as a Byzantine chant. Some emphasize the beauty and "power" of archaic texts and words in Church Slavonic and Ancient Greek, which generate different experiences and meanings even for people who do not speak the languages. Many are "moved" by compositions of Finnish musicians and choir conductors, who artistically combine (neo-)Byzantine chants, Slavic multivocal traditions including "znamenny chant," and modern influences. Prayers also invoke the notion of home at different levels. They refer to church as the dwelling place of God, to Mary as "the marvelous palace of the Lord," and to one's own body as "the house of the Divine Spirit." 43 For Russian-speaking interlocutors, this connection is also literal: The Russian word dom means both "house" and "home."

Nevertheless, the artistry and agency of individual participants are equally crucial. The glocal making of the Liturgy as a communal happening requires learning, practice, interaction, tuning, and contemplation on the part of all attendees. Finnish faithful participate in services in different languages; many are well familiar with some recited prayers in Church Slavonic and Ancient Greek sung during the Liturgy as well as famous hymns such as the paschal troparion "Christ is risen from the dead." Moreover, Russian- 
speaking participants also learn prayers and hymns in Finnish to enable their fuller participation in Finnish-language liturgies.

The Liturgy as glocal homemaking is also a process that triggers tensions and necessarily involves the negotiation of such tensions. Older Karelian women, while admiring converts' arduous efforts to study Orthodoxy, could reproach them for their conduct at church, such as their tendency to wear "only black" during the Liturgy, which was not customary in pre-war Karelia. The older women also commented on converts' tendency to educate others on Orthodox doctrine based on their learning and "book knowledge." Some cradle Orthodox-Karelians as well as descendants of Russian émigrés of the era of the grand duchy-found it difficult to deal with the more recent influx of Orthodox migrants, as it meant that what they knew as their cozy, small, "home church" had become a very different place altogether. At the same time, Russian migrant women could feel tense and uncomfortable attending the Liturgy in the Finnish language, especially when they were newcomers at the OCF. In some parishes, the estrangement between Russian speakers and Finnish speakers could also be enhanced by nationalistic interpretations of history, in particular concerning the cessation of Karelia from Finland to the Soviet Union in the aftermath of World War II. Some of our interlocutors, as well as the clergy, made efforts to ease these tensions in their work in the parish.

However, what united our interlocutors irrespective of their backgrounds was how they related to the Liturgy as their "spiritual home." While many of our interlocutors were well familiar with the theological significance of the Liturgy, when they described their personal experiences they turned to the language of feelings and bodily sensations, associated with a comforting sense of "being at home." Many women linked their partaking in the Liturgy with senses of "joy," "solemnity," "serenity," "calmness," and "silence," emphasizing the Liturgy's "nurturing" and "therapeutic" effects. They liked "breathing in the air, the smell of the incense." Some felt "comforted" by the "shining" and "smoothing" beauty of surrounding icons. Others experienced "awe" and "reverence" looking at "the sky with the stars" in the church dome. Many also referred to spontaneously occurring bodily reactions to describe the inexplicably touching nature of chants and choral singing. Listening to the choir could make your body "tremble," "chill" you "to the marrow of your bones," "make your heart go soft," or "move" you "to tears." Overall, during the Liturgy a church could be so rich with atmosphere that "religion is almost palpable" there. Such accounts convey the agentic nature of the women's individual, contemplative, and sensual engagements with the Liturgy, in which a sense of the inner home is central. ${ }^{44}$

Finally, most of our interlocutors also emphasized their ongoing efforts to "master" the Liturgy. While they experienced the Liturgy as a homelike space, they simultaneously conceived of it as a continuous spiritual and cognitive journey. It takes years of practice and work to learn the language of Liturgy, with the visual elements, "church poetry," and music all intertwining theological meanings with personal experiences felt in the body. Indeed, as one of our older Karelian interlocutors, Elsa, stated, "We are never ready in this area," for "everything is revealed so very slowly." The same notion was expressed by one of the younger women, Johanna, who emphasized how "all services are different." The women, overall, spoke of the Liturgy as a space for "deepening" one's spiritual knowledge and "developing" as a person. Many interpreted their evolving experiences of the Liturgy in the context of their progress through different life stages. In other words: As religious virtuosi, the women also approached the Liturgy through their personal spiritual goals and their aspiration to embody Orthodox traditions to the fullest. 


\section{Family Making through Home Altars}

Women's creativity and artistry in constructing and sustaining the feeling of "being at home" often receives its fullest expression in the domestic setting. In a previous publication, Helena Kupari has argued that the everyday religious customs of her elderly Karelian interlocutors can be understood as agentic practices of homemaking. ${ }^{45}$ Through these customs, the women sustained a domestic environment in which religion was continually present in various material, sensory, and temporal clues. Moreover, this crucially contributed to their experiences of the safety, stability, and sanctity of domestic space. Here, we develop this line of thought further, suggesting that religious homemaking also involves building connections between past and present homes as well as between homes of loved ones across geographical distances. In addition, we argue that homemaking activities are closely connected to family making, to maintaining loving and emotional relationships and creating "family feeling" among family members.

For both our older and younger generation of interlocutors, religion was intertwined with family relations. The older Karelian women had been brought up in all-Orthodox families in which religion was openly practiced and passed on to the children. In their descriptions of their religiosity, they focused on lineages and continuums of practice reaching from childhood to old age. Sometimes they further emphasized the deep-seated nature of their religiosity through the use of corporeal metaphors. They could speak, for instance, of Orthodoxy being in their "genes" or of having received it through their "mother's milk." These expressions conceive of religion as a concrete, physical, and embodied connection between family members.

In comparison to these elderly women, many of our younger interlocutors had not been actively guided toward an Orthodox lifestyle in childhood. On the one hand, in the Soviet Union, decades of systematic suppression of religion had resulted in Orthodoxy being only nominally present in most people's lives. On the other, in post-World War II Finland the open practice of and identification with Orthodoxy was often restrained because of discrimination. In addition, the postwar decades brought about a surge in marriages between Orthodox and Lutherans, and collective familial religious practice in these biconfessional families was commonly biased toward Lutheranism. ${ }^{46}$ Therefore, although for different reasons, both our Russian- and Finnish-speaking informants of the younger generation often had mainly passive experiences of Orthodoxy from their youth.

Nevertheless, in their later rediscovery of Orthodoxy, these women drew on childhood memories of their Orthodox family members. For example, many Russian-speaking women cherished embodied recollections of their grandmothers praying, lighting a candle in front of an icon, or reciting a silent prayer before eating. In the Soviet Union, children's religious socialization and the transference of religious traditions was left mainly to grandmothers, or babushkas. ${ }^{47}$ In this vein, our Russian interlocutor Anna, a "militant atheist" in the past (in her own words), recounts how her grandmother was the only family member who connected her to Orthodoxy:

I was born into a non-Orthodox family. ... My mother was not Orthodox, although her mother was faithful. . . I I was baptized by my babushka [maternal grandmother], probably kept secret from my father, I don't know the exact story. Then, I went to church with babushka several times. Babushka prayed before she went to sleep; I heard her praying when I stayed at her place. She also had icons, so in 
some ways it [Orthodoxy] was in my surroundings. I had a sense of it but was quite unconcerned about it. I had a cross, I did not wear it, but it was, it has always been there, and now I am wearing it. ... There is a family legend related to it, that it was made from a family silver spoon [laughing].

Our older Karelian interlocutors also often singled out a close female relative-commonly their mother or grandmother-as their primary religious role model. They described this person as having been particularly devout in her religious observance. In their own practice of piety, they strived to follow the example set by their predecessor. Our interlocutor Hilja, for example, described how, after her grandmother passed away, she bequeathed her with the task of intercessor:

After we had come home from my grandmother's funeral, I had this dream in which she was waking me up. And she said to me: "You poor child do not pray enough, for I have to pray for you here in the afterlife." ... I have thought to myself that grandmother must have been such a holy person-she wasn't free of sin or anything, but she was so devout in her faith and she prayed for me and for my children and for everyone-that she was able to send me a message, to remind me not to forget to pray. Because she herself turned to God all the time, asking for God's help and blessing.

A similar experience was also narrated by our Finnish interlocutor Marja, of the younger generation. She had been baptized into Lutheranism as a child but had later converted to Orthodoxy. Her maternal grandparents had originally been Orthodox, but her grandmother had left the Church in adulthood to avoid social exclusion in postwar Finland. Then, the night her grandmother had died, Marja had felt that she had come to sit on her bed for a while. Marja's, Hilja's, and Anna's narratives all illustrate how our interlocutors conceived of their religiosity as family tradition passed on from grandmothers to granddaughters.

At the heart of domestic religious practice in Orthodox Christianity are home altars, also known as icon corners (ikoninurkkaus in Finnish, krasnyi ugol in Russian). The home altar, traditionally set up in the corner of one habitable room (or several rooms) of the home, is where family icons are placed, potentially accompanied by other religious objects and paraphernalia such as the Bible, prayer books, religious print images, hanging oil lamps, wax candles, and religious textiles. Sarah Riccardi-Schwartz summarizes the centrality of icon corners in vernacular Orthodoxy by noting how they act as portals and mediators that "allow access to the extended family of Orthodox Christians, living and dead, humans and saints, thereby strengthening religious, social, and familial bonds." ${ }^{48} \mathrm{Here}$, we focus on home altars as facilitators of family making within and beyond the nuclear family.

Irrespective of generation or ethnic background, intercessions for loved ones were an integral part of our interlocutors' domestic religious practice. In the interviews, many of them recounted memories of troubled times, during which they had prayed ardently for resolution in front of the home altar. Marja, for example, described how her most powerful experience of divine intervention to date had occurred when her son was seriously ill. He was six years old at that time, and Marja had to leave him in the hospital. She came home with a heavy heart and prayed devotedly in front of a Marian icon that her Orthodox grandfather had painted for her. The same day Marja received a call from the hospital that she could come and take her son home: He had recovered. Several other women also shared with us similar intense experiences of divine guidance that they had received in response to their motherly prayers in times of crisis. 
Motherly and grandmotherly prayers were also included in the women's daily religious observance. Many of our younger interlocutors were occupied with starting families and caring for their children. Our older interviewees, for their part, often understood praying as the particular duty of grandmothers. What differentiated the two groups of women was that the older generation's practices were equally geared toward crossing temporal distances and the barrier separating living and deceased family members. They were worried about what would happen to their offspring after they themselves had passed away. Toini, for instance, stated: "I've thought that I have to pray [for my children and grandchildren] so much beforehand that it will carry them even after my death." Furthermore, many of their loved ones had already died. Therefore, practices of remembering the departed were an important part of their engagements with their home altars.

Our interlocutors, overall, saw prayer as powerful agentic action. ${ }^{49}$ By interceding on their behalf, the women were able to help loved ones and family members across vast distances. Prayer could also cross the barrier between this world and the hereafter. Many women thus emphasized the "power of prayer" in situations in which all other means of action had failed. Simultaneously, they also acknowledged that the effects of prayer could not be accredited to them alone. To the contrary, praying was essentially about acknowledging one's dependence on God, resigning oneself to God's will, and begging for the support of divine intercessors. According to the women's religious worldview, one could tap into enchanted agency, thereby significantly expanding one's capacity to act in the world-but only through submission to and humble collaboration with the sacred personages of the Orthodox universe. ${ }^{50}$

The Mother of God is the divine intercessor many of our interlocutors primarily turned to when praying for their children and grandchildren. Mary, that is to say, stood at the center of their mothering and family practices. In Orthodoxy, the Virgin is often seen as a perfection of humankind. ${ }^{51}$ As an exoteric figure, she stands for the mystery of birthing and nurturing God within the self, metaphorically applicable to men and women. ${ }^{52}$ Nevertheless, many women also approach her as the one who, being a mother herself, best understands a mother's pain, sorrow, worries, and joy, while also having invincible powers to intercede and cure. ${ }^{53}$ This engagement happens primarily through the many icons of the Mother of God, each with its own story and iconography..$^{54}$ Marian icons thus had a prominent place in our interlocutors' home altars.

For our younger, migrant interlocutors, home altars had additional significance as tangible spaces of family making. These women commonly operated with an extended notion of a family that transcended national borders, encompassing relatives "here" and "there." The women's activities focused on crossing spatial distances through visits and with the help of new telecommunication technologies, as well as influencing the lives of loved ones abroad. Often, their home altars became important glocal sites where the entire transnational family was brought under the protection of the Trinitarian God, Mary, and the saints.

A case in point is our Russian interlocutor Elena's home altar, located in the living room of her apartment in Finland. The altar housed many divine figures. There was a large printed icon of the Valaam Mother of God and a copy of the famed Vladimirskaya icon of the Mother of God, with the Christ child gently nestling and embracing the neck of his mother. The altar included icons of the patron saints of her three children, her husband, and herself. There was also an icon of Saint Nicholas, to whom she prayed for her brother Nikolai, living in Germany, a musician with a long and sad history of drug addiction and mental illness. An icon of Saints Sergius and Herman of Valaam helped her "feel 
connected to her home in Sortavala" in Russian Karelia. In its entirety, Elena's home altar constituted a space of glocal homemaking, in which her different senses of belonging manifested. The altar reproduced the sense of togetherness and familyhood against the odds of separation, with icons functioning as talismans of belonging and saints taking the role of divine members of her transnational family.

Elena's family had experienced a great deal of uncertainty caused by Finnish residence permit procedures and a precarious job situation. In her narratives, the home altar-and particularly the Marian icons of the icon corner-emerged as an anchor of family belonging, security, and "calmness" in the midst of transnational changes and the challenges of adjustment in Finland. The following quotation from Elena's interview beautifully illustrates how, when praying together, her family grows into one body, one corporeal unit, under the protection of invincible powers. This family bonding takes place not only as a spiritual unit but also literally, in the space of a Marian icon:

Life goes very quickly. There are a lot of everyday things taking place. But when you gather with your family to eat in the evening ... when we pray before eating, we hug each other at the same time. I don't know, but it just happens instinctively. For instance, Maria, our daughter, can't just stay separately and pray. She will come and embrace me, and then we all stand together. And this prayer before we eat seems to be a small thing, but at that moment, when we're hugging each other, praying, I feel that we are a family and we are strong. Whatever happens, we are together and have each other ... I look at the icon [the Valaam Mother of God], and it is like an unconditioned reflex of calmness.

Icons of the Virgin held a special significance for many of our other migrant interlocutors as well. Besides their role in practices of mothering, they could also function as bridges between the women's past and present homes. Many women thus developed their home-relatedness to Finland through interacting with familiar Marian icons, at the same time retaining their sense of Russian belonging. ${ }^{55}$ The Valaam icon of the Mother of God is a good example. Due to particular historical trajectories, there are presently two Valaam (Valamo in Finnish) monasteries, one in Lake Ladoga in Russian Karelia and the other in Heinävesi in eastern Finland. ${ }^{56}$ The original icon of the Valaam Mother of God is presently one of the main treasures of the Finnish monastery, while an exact copy of this icon is kept and venerated in the Russian monastery. In a sense, the wonder-working icon is equally connected to both monasteries, creating a glocal space in which the boundaries of national imaginaries between Russia and Finland can be transgressed.

The glocal nature of home altars was also evident in our older Karelian and younger Finnish interlocutors' homes. Many of the younger women, especially, were well aware of the historical and cultural background of the icons that they had set up in their icon corners. ${ }^{57}$ Home altars could include icons or print images bought as souvenirs from travels abroad, carrying connotations of different national contexts. Nevertheless, for most women Karelian icons were particularly important-for family reasons and given the special role that these icons had in Finnish Orthodoxy and the OCF. Besides the Valaam Mother of God, other popular and respected icons were those of the Konevets (Konevitsa in Finnish) Mother of God and of Saints Sergius and Herman, the legendary founders of the Valaam Monastery. Our interlocutor Irene, of the older generation, had placed an icon of the Konevets Mother of God at the center of the icon corner in her living room and had recently commissioned similar icons to be painted for her children. She explained: "The Konevitsa Mother of God is very important to us Karelians, because it has been brought from Athos here to the Konevitsa Monastery. This [icon] motif is 
very familiar and much loved in Karelian homes." In fact, the Konevets Mother of God is another icon that opens up a transnational connection between Russia and Finland. It is linked to the Konevsky Monastery in Russian Karelia, but at present the original wonder-working icon is kept in the Valaam Monastery in Heinävesi.

For many of our older Karelian informants, home altars constituted transtemporal as well as transnational spaces. They had placed icons inherited from parents, grandparents, or other relatives at prominent places in their homes. Some women had also included in their home altar a print version of a particular icon of Christ Pantokrator. This print is commonly known in Finland as "the Evacuee Christ" (Evakko-Kristus in Finnish) because copies were distributed to evacuated Orthodox families during World War II. Placed in the icon corner, it acted as a concrete reminder of the women's histories of displacement. In addition, many of these women had formed a close attachment with icons depicting the patron saint of the church or chapel of their childhood home village in Karelia. In the home altar, these icons also facilitated a sensual and material connection with the past.

All of these examples emphasize our Russian, Karelian, and Finnish interlocutors' artistry in arranging their home altars and agency in breathing life to their domestic environments through their daily prayers, contemplation, and interaction with icons. Through their practices, the women construed connections between their past and present homes and between homes "here" and "there," united their families dispersed in space and time, and cared for their loved ones both near and far. Through their customs, they also honored their family religious traditions and tapped into the legacy of their religious role models. Simultaneously, they created glocal environments in which elements from various contexts merged together, producing unique fusions of personal, local, national, and transnational significations.

\section{Women's Agency in Parishes}

In the OCF, women have historically had a prominent role in various bodies vital to the functioning of parishes, such as church choirs and clubs. At present, women's representation in elected councils of parishes is also equal to that of men. Women are often in charge of lay activities such as the organization of church fairs, children's clubs, and cultural and educational events. ${ }^{58}$ Many of our interlocutors of both generations had taken part in such projects. Here, we discuss some of their experiences of parish activities. Through these activities, we demonstrate, the women exerted their more intentional, change-driven, and goal-oriented agency for the benefit of the community.

Many of our older Karelian interlocutors had recently had to limit their participation in parish life for health reasons. Yet they could be considered active members of the OCF. Some had taken part in parish pursuits throughout their lives, whereas others had begun attending more regularly after their children had grown up or when in retirement. While the women had experience of many different kinds of activities, we focus here on the form of voluntary activity most familiar to them: the Tuesday Club (Tiistaiseura in Finnish). Tuesday Clubs are local branches of the Finnish Orthodox home mission organization Brotherhood of Saints Sergius and Herman, which has close ties to Orthodox parishes. The first branches were founded in Karelia in the 1920s. While the heyday of the Tuesday Clubs was between the 1950s and 1980s, during past decades their significance for parish life has diminished. Today, the membership of the Tuesday Clubs mostly consists of the parish elderly. ${ }^{59}$ 
Tuesday Clubs are commonly led by prominent female parishioners, and their members are predominantly women. The gender bias reflects the nature of the activities offered. Traditionally, Tuesday Club meetings (held on Tuesdays) consisted of handicrafts or needlework, coffee, and some spiritual or cultural program such as prayers, singalongs, guest lectures, or recitals. A central function of the clubs was to gather funds to be used on some worthy cause. Collectively, participants produced crafts and baked pastries that were sold at church fairs, the proceeds of which were used to benefit the parish or donated to some other spiritual cause. Furthermore, Tuesday Clubs could also contribute to the parish through catering church coffees, producing festival decorations, or helping in the cleaning and maintenance of parish property.

When describing Tuesday Clubs, our interlocutors emphasized the warm atmosphere and solidarity among participants. They could speak with affection of already deceased older members who had given them guidance or acted as spiritual role models. Many also had childhood memories of their mothers attending Tuesday Club meetings. For these women, taking part was yet another way of honoring their spiritual family heritage. Furthermore, as in their daily lives most women were surrounded by people who did not share their confession, Tuesday Clubs constituted rare spaces where they could enjoy the company of other likeminded Orthodox practitioners and, as one of them stated, "rejoice in being part of a community."

During the first post-World War II decades, the OCF went through a massive reconstruction project. It had lost an estimated 90 percent of all of its property in the war. ${ }^{60}$ The state provided funds for the construction of new churches and parish halls; moreover, chapels were also financed through local fundraising projects or built entirely by community labor. Tuesday Clubs had a significant role in the furnishing of these places of worship and in supplying them with ritual objects, textiles, dishes, utensils, and other necessary equipment. When discussing the history of the OCF, several of our older interlocutors thus noted with pride how many Orthodox chapels were the result of "the activity of parishioners" and "the hard labor of Tuesday Clubs."

These women often remembered the buzzing activity of previous decades with fondness. According to them, Tuesday Clubs used to be places of intense work where a lot could be achieved through collective effort for the benefit of the entire community. In their accounts, they often contrasted the past with the present, noting that Tuesday Club members no longer had the same energy or sense of purpose. As the membership had aged, meetings had increasingly focused on socializing and spiritual content. Our interlocutor Soja lamented that in the club that she frequents volunteers could no longer be found to cater for church coffees on a weekly basis. She strongly disapproved of this development. Her description of the activity of previous years emphasizes friendship and solidarity as a motivating factor and conveys her sadness over losing it:

Then, when the children grew older, I was freer to participate and go [to parish activities]. . . At some point Father Petri asked me if I spent any time at home at all [laughing]! I was not in so much of a rush to get home because the children were already so much bigger by then. And we baked pies and other pastries, we always had something in the freezer that we could serve [at church coffees]. We had this really nice group of people. One of us just died, Nina, a year ago. And then Helmi. I used to sew with her, church textiles and everything, down in the basement [of the parish hall]. We had a sewing machine there and a loom and fabric and ... now there's a lack of organizers. 
Our Karelian interlocutors also described Tuesday Clubs as gatherings where the participants used to be mostly Karelian, and the meetings included many ethnic elements. This enhanced their feeling of "being at home" in the parish. However, the women who had been upholding these traditions had since passed away, and the membership had become more heterogeneous. While in the eyes of other attendees our interlocutors undoubtedly embodied Karelian Orthodoxy, they themselves felt that something had been lost. "What has happened to Karelianness?" asked our interlocutor Kielo when observing that Tuesday Club meetings used to include singalongs in the Karelian dialect but that nowadays "no one knows or sings any songs." Nevertheless, many of the women had actively passed on their knowledge of Karelian traditions to younger parishioners through, for example, teaching them how to prepare traditional dishes or handicrafts.

Compared to the older Karelian women, our younger interlocutors were at a different stage of their lives. Their participation in parish pursuits was not hampered by their ailing health. On the contrary, many of them contributed a lot of their time to the parish despite their busy schedules. In their accounts, they described the church as a homelike environment, a feeling caused, at least in part, by their ongoing, active participation in the constitution of this space.

The women were members of a large urban parish, which in Finland are usually more multicultural than rural ones. Many of them appreciated the parish clergy for their efforts to encourage interaction between members from different backgrounds. In the parish, the Liturgy is celebrated in several languages, and most clubs and groups operate bilingually, in Finnish and Russian. However, lay women's role remains vital in maintaining the parish as a glocal space through their daily practices and participation. Our interlocutors organized church fairs and cultural events on a voluntary basis, exerting a great deal of artistry in joggling between paid work, church, their families, and other social relationships and engagements. Nevertheless, similarly to the older Karelian women, they described their collective efforts as "joy," whether when singing in "good company" or simply "doing things together." Most of them perceived the multiculturalism of the parish as a self-evident fact and as something that positively influences the life of the parish. As one Finnish choir singer put it: "It is great that one can hear many languages spoken."

In the parish under study, the majority of choir members are women. Alongside weekly practices, the choir performs in concerts, travels abroad, and arranges choral camps, especially in preparation for the elaborate Easter service, seen as the high point of the church year. The singers come from different ethnic and linguistic backgrounds, and not all of them are Orthodox by confession. Finnish-speaking women, especially more experienced ones, support and help non-native speakers and younger members. Some of our Russian-speaking interlocutors explained that attending choir practices helps them immerse in the Finnish-language Liturgy. Certainly, the women were also committed to singing in liturgies celebrated in Church Slavonic, thereby contributing to the glocal nature of the parish. During our fieldwork, many participants emphasized that singing in the choir was "rewarding" and "satisfying" on many levels. Some pointed out that it helped them maintain emotional balance and had a therapeutic, calming effect. Others noted that they felt blessed to "sing to the glory of God" and thus participate in a sacred act. Furthermore, our interlocutors also saw their choir practices as a way of bonding with "good" individuals and people of faith. Our Finnish interlocutor Marjaana, a convert to Orthodoxy, noted: "When I first came to a choir practice, I felt that I had found it, my own thing. I kept going, and I was delighted to meet people there. It was a wonderful feeling to be part of this community, singing, and prayers." 
In some cases, the women recounted specific events and instances when singing in the choir had been especially moving and had enhanced the personal experience of the divine. This is how our Russian interlocutor Anfisa described the Forgiveness Sunday service, which commences Lent:

I had never before been present at this kind of service, where everybody in the temple was walking around and asking one another for forgiveness. We were singing Easter hymns . . . and the choir was big, and it made a big difference, everybody was moved. I don't know about the others, but I got goose bumps all over my body, it was a great feeling. I felt like crying. And many in our choir cried. It was indescribable.

Besides the choir, another interactive space of grassroots glocalization is children's theater performances, which are usually arranged for Christmas and Easter celebrations. In this parish, Russianspeaking women are especially active in creating such performances. Our interlocutor Natalia, a medical doctor by occupation, first took the initiative, supported by the youth council of the parish and a friend who run a children's art club in the parish. Soon several other highly educated women joined. The production usually includes the following steps, all managed by the women during their free time: writing a script, translation of the script into Finnish (if written in Russian), making decorations, preparing the musical arrangement (including negotiations with the choir), and multiple rehearsals with the children. The performances have been carried out in various forms, including puppet theater and shadow plays. They commonly take place after the Liturgy in a big hall, with all the parish, especially the children, watching. When asked about the motivation driving these titanic efforts, our interlocutor Milana elaborated:

The desire that children would apprehend all these biblical events, that they would be able to live them as a miracle, as a fairytale, yes, as a miracle. Usually, in life outside the Church, there is just a present for Christmas, but the fairytale has been taken away. ... Through this [performance], there is an opportunity to bring joy, to immerse in the lives of the saints, who were also historical figures, through this fairytale. ... One mother said to me: "You were worried that it did not quite come out right, but my child, for three days after the performance, was walking with a star, playing the three wise men." They [children] absorb it on some different level. These dolls [pointing to the handmade puppets] are no comparison to dolls from the shop. Here is an opportunity to partake in something else. It is almost like icon painting. And when you make it, it is such a joy, that you do something real. It is nice when people are united, they come and take part. When we do it all together, it is such a joy.

The quotation illustrates women's multifaceted agency in arranging these theater performances. First, it points to their motherly impulse to reenchant Christmas for their children. In speaking of fairytales and miracles, the women, perhaps unwittingly, conveyed that religion is connected to mythmaking, "myths" referring here to "true stories" that relate to reality in an imaginative way. ${ }^{61}$ As Anna put it: "Maybe, we create memories for our own children in hopes that they would be able to rely on them in adulthood, for a more mature apprehension of Orthodoxy." Second, according to Milana, putting together these performances parallels icon painting in that you produce material representations of and portals to sacred reality. Similarly to participation in the Liturgy, enacting Christmas and Easter through theatrical means thus provides an opportunity for sensual partaking in the mysteries of birth, sacrifice, rebirth, and resurrection. Third, Milana also refers to the collective agency involved in preparing the performances and uniting people from different backgrounds. 
Nevertheless, tensions are an unavoidable part of this process as well. Conflicts may occur during the production, for instance while negotiating with the youth council or the choir. Also the participants themselves can hold differing views on the nature of the performances. Some women, for instance, noted that they did not approve of "preaching." Thus, after negotiations the participants agreed to focus on telling biblical stories in a beautiful and engaging way rather than to emphasize the performances as pedagogical tools. This agenda is also reflected in Milana's narrative.

The theater productions, all in all, are excellent examples of glocalization in the making. Through them, many migrant women of the parish under study expressed their creativity and artistry and channeled their multifaceted agency in the OCF. Simultaneously, the women were conducive to making the parish a homelike environment for themselves, their children, and others. As shown in numerous studies, Russian speakers often feel the need to suppress their ethnic identity while living in Finland. ${ }^{62}$ AntiRussian discourses have influenced the Finnish cultural landscape ever since the rise of Finnish nationalism in the nineteenth century. Today, these sentiments are further enhanced by utterly politicized negative accounts of Russia in Western media. ${ }^{63}$ While Russian speakers can experience marginalization in Finnish society, many of our interlocutors described the local Orthodox parish as a "safe" space, where they and (more importantly) their children could be openly Russian without being ridiculed or discriminated. Producing the performances in the Finnish language, however, was a conscious decision. As our interlocutor Elena explained: "We live in Finland, and we want everybody to be involved."

\section{Conclusion}

The objective to develop and defend the existence of a specific Finnish form of Orthodoxy has characterized the OCF throughout its history as an autonomous church. Over the course of time, this agenda has resulted in the highlighting of certain cultural forms and influences and the downplaying of others. During the latter half of the twentieth century, for instance, the Byzantine roots of Orthodoxy were often stressed at the expense of the OCF's concrete ties to the Russian Church. More recently, the Church has invested in reviving and incorporating Karelian and Russian elements in the life of the Church-while not necessarily articulating this explicitly. Our starting point in this chapter has been to approach Orthodox Christianity in Finland as a glocal religion. Through the lens of glocalization, it is possible to shed light on these kinds of historical dynamics, which are easily neglected when the focus is squarely on the OCF as a particular national manifestation of Orthodoxy.

The essence of our discussion has been lay women's contribution to the ongoing glocal becoming of Orthodoxy in Finland. We have demonstrated how our interlocutors participated in this process through both passive and active means. These include, first of all, their very presence in and conduct during church services and their competence and will to learn more of the various elements that make up the Liturgy. Second, the women were pertinent to the grassroots glocalization of the OCF also because of their active efforts to promote practices of importance to them in the parish and to negotiate for the inclusion of different ethnic traditions. The women's home altars, moreover, functioned as glocal religious spaces in which icons and mementos from different cultural contexts merge. Icons with ties to several contexts are applied to transgress national imaginaries and bring together the women's multiple senses of belonging. In fact, our interlocutors also engaged with these icons in more public settings such 
as churches and monasteries, thus enriching the discursive space surrounding the icons in contemporary Finland with their personal interpretations and narratives.

Theoretically, our interpretation of the women's practices draws from and advances discussions concerning gendered religious agency. We have proceeded from the premise that women's virtuoso religiosity can and should be seen as agentic action. Furthermore, to disentangle our conceptualization of agency from simplistic juxtapositions between compliance and resistance, we have focused, instead, on the multivalent nature of agency. Making use of notions developed in material and vernacular religion scholarship, we have argued that women's religious agency encompasses also their sensual engagements with and artistic and creative applications of religion. In our study, we have taken notice of, for example, our interlocutors' contemplative spirituality, their personal interpretations of religious traditions and teachings, and their flexible juggling between religious and secular responsibilities. Irrespective of generation and ethnic background, maternal concerns and impulses were an important factor in the women's devotions. They channeled their agency into practices of nurturing and caring, which extended from their children to relatives and the wider religious community. Overall, many manifestations of the women's agency were characterized by relationality, altruism, and submissiontheir understanding of prayer being a case in point. However, the women did also exert active and project-oriented agency, for example through their voluntary work in parishes.

In this chapter, furthermore, we have examined women's activities both at church and home as practices of dwelling. ${ }^{64}$ Our interlocutors' agency, we have suggested, can be understood as their capacity to create and sustain homelike spaces where they can express themselves, be united with their (extended) families, experience existential security and belonging, and generally speaking feel "at home." This homemaking was tied to the women's personal spiritual pursuits as well as to their gendered social roles as keepers of the home and family. Moreover, it was also an endeavor that required constant negotiation between the orientations and preferences of different people, ranging from family members to other parishioners. We have chosen not to accentuate here the difficulties and failures that the women faced (although we have provided some examples of these as well) but to stress the enabling and empowering aspects of their religiosity. Nevertheless, to end our discussion we articulate an important difference in the experiences of our two groups of informants, related to their sense of "being at home" in the OCF.

In the interviews, the women of the younger generation mostly emphasized the OCF as a welcoming and inclusive environment. Our Russian interlocutor Natalia, for example, stated: "When we came here, and, of course, came to our church, our parish, it was as if I came to my native home. Thanks to it, our family immersed in all this, and found activities, friends, and hobbies. . . We found a warm place, our place." The older Karelian women, in contrast, spoke of the atmosphere of the Church in more ambiguous tones. On the one hand, it was still their native Church, the Church of their ancestors. On the other, they noted that it had gone through changes, which made it hard for them to feel completely at ease there. Soja summarized the crux of the matter: "They don't care about Karelianness anymore, these [newcomers] who come from elsewhere and join with their own ideas. Karelians are Karelians, but soon they will be no more, when all the old people have passed away."

The feeling of "being at home" is not something that can be attained once and for all. Rather, it needs continuous upholding. Especially in the case of people who do not belong to the dominant faction of the community in question - as is often the case with women, migrants, and the elderly-the ability to feel 
at home is dependent on their active struggle for inclusion. The experiences of our two generations of interlocutors well illustrate this dynamic. The younger women, through their active immersion in the life of the church, had made it their own. The older women, for their part, could no longer partake as fully as before. They felt a degree of exclusion, often nostalgically reminiscing about the communality of past decades. These experiences, moreover, also demonstrate how the glocal becoming of a community is understood differently by differently positioned members. Glocalization is an ongoing process in which cultural forms fuse, transform, and shift places in a kaleidoscopic fashion. Our interlocutors' accounts show that while some OCF members greatly value the possibilities offered by the Church to act out their transnational subjectivities and expand their cultural horizons, others lament the diminishing significance of elements that they consider essential to the very identity of the Church. This perceived tension reflects the vitality of the process of glocalization in multicultural parishes that incorporate transnational elements and manifold manifestations of home and dwelling in their activities.

Notes

${ }^{1}$ After displacement from Karelia, the percentage of interconfessional marriages among matrimonies entered into by members of the OCF quickly rose to 90. Furthermore, during the first postwar decades, the baptism of children following the father's religious affiliation was the norm in Finland. Voitto Huotari, "Orthodox-Lutheran Intermarriage in Finland," Social Compass 38, no. 1 (1991): 25-31.

${ }^{2}$ Kimmo Kääriäinen, Kati Niemelä, and Kimmo Ketola, Religion in Finland: Decline, Change, and Transformation of Finnish Religiosity (Tampere: Church Research Institute, 2005), 82, 88-92; Statistics Finland, "Population Structure on 31 December," https://www.stat.fi/tup/suoluk/suoluk_vaesto_en.html.

${ }^{3}$ Tuomas Martikainen and Teuvo Laitila, "Population Movements and Orthodox Christianity in Finland: Dislocations, Resettlements, Migrations, and Identities," in Orthodox Identities in Western Europe: Migration, Settlement, and Innovation, ed. Maria Hämmerli and Jean-François Mayer (Farnham: Ashgate, 2014), 153.

${ }^{4}$ Martikainen and Laitila, "Population Movements," 155-56.

${ }^{5}$ See Martikainen and Laitila, "Population Movements," for a detailed account.

${ }^{6}$ Juha Riikonen, "The Nationality Question in the Orthodox Church of Finland," in The Two Folk Churches in Finland: The 12th Finnish Lutheran-Orthodox Theological Discussions 2014, ed. Tomi Karttunen, trans. Rupert Moreton (Helsinki: National Church Council, Department for International Relations, 2015), 96104.

${ }^{7}$ Martikainen and Laitila, "Population Movements," 160.

${ }^{8}$ Martikainen and Laitila, "Population Movements," 164.

${ }^{9}$ Statistics Finland, "Population Structure." 
${ }^{10}$ Tomi Karttunen, ed., The Two Folk Churches in Finland: The 12th Finnish Lutheran-Orthodox Theological Discussions 2014, trans. Rupert Moreton (Helsinki: National Church Council, Department for International Relations, 2015).

${ }^{11}$ Martikainen and Laitila, "Population Movements," 166.

12 Statistics Finland, "Population Structure."

${ }^{13}$ Tuomas Martikainen, Religion, Migration, Settlement: Reflections on Post-1990 Immigration to Finland (Leiden: Brill, 2013), 103-7.

${ }^{14}$ World Values Survey, Finland 2005, http://www.worldvaluessurvey.org/WVSDocumentationWV5.jsp.

${ }^{15}$ Annika Jonninen, “<HS>'Toivoisin, ettei vähenisi': Tutkimus ortodoksisen uskonnon opettajista sekä ortodoksisen uskonnon opetuksen tilanteesta lukuvuonna 2012-2013," master's thesis, University of Eastern Finland, 2014, 22-23; Valeria Mäkirinta, "Suomen ortodoksisen kirkon kanttorin ammattiidentiteetti: Mielikuvia työstä ja työntekijästä," master's thesis, University of Eastern Finland, 2014, 29.

${ }^{16}$ Katariina Husso, "Obedient Artists and Mediators: Women Icon Painters in the Finnish Orthodox Church from the Mid-Twentieth to the Twenty-First Century," in Orthodox Christianity and Gender: Dynamics of Tradition, Culture, and Lived Practice, ed. Helena Kupari and Elina Vuola (London: Routledge, 2019), 75.

${ }^{17}$ Statistics Finland, "Population by Religious Community, Age and Sex in 2000 to 2017," Statistics Finland's PX-Web databases: Population structure 016, http://pxnet2.stat.fi/PXWeb/pxweb/en/StatFin/StatFin_vrm_vaerak/?tablelist=true.

${ }^{18}$ Kääriäinen, Niemelä, and Ketola, Religion in Finland, 134-44; World Values Survey.

${ }^{19}$ Kääriäinen, Niemelä, and Ketola, Religion in Finland, 60-61.

${ }^{20}$ E.g., Husso, "Obedient Artists and Mediators."

${ }^{21}$ E.g., Pekka Metso, "Keskustelu samaa sukupuolta olevien parisuhteesta Suomen ortodoksisessa kirkossa vuodesta 1990 nykyhetkeen," Ennen ja nyt: Historian tietosanomat 1 (2018), http://www.ennenjanyt.net/2018/02/keskustelu-samaa-sukupuolta-olevien-parisuhteesta-suomenortodoksisessa-kirkossa-vuodesta-1990-nykyhetkeen/.

${ }^{22}$ Andreas Kalkun and Elina Vuola, "The Embodied Mother of God and the Identities of Orthodox Women in Finland and Setoland," Religion \& Gender 7, no. 1 (2017): 37-38, https://doi.org/10.18352/rg.10165.

${ }^{23}$ E.g., Frederique Apffel-Marglin, Subversive Spiritualities: How Rituals Enact the World (New York: Oxford University Press, 2011); Saba Mahmood, "Feminist Theory, Agency, and the Liberatory Subject: Some Reflections on the Islamic Revival in Egypt," Temenos: Nordic Journal of Comparative Religion 42, no. 1 (2006): 31-71.

${ }^{24}$ Roland Robertson, "Glocalization: Time-Space and Homogeneity-Heterogeneity," in Global Modernities, ed. Mike Featherstone, Scott Lash, and Roland Robertson (London: Sage, 1995), 27. 
${ }^{25}$ Daniel Nehring et al., Transnational Popular Psychology and the Global Self-Help Industry: The Politics of Contemporary Social Change (London: Palgrave Macmillan, 2016), 33.

${ }^{26}$ Victor Roudometof, Globalization and Orthodox Christianity: The Transformations of a Religious Tradition (New York: Routledge, 2014).

${ }^{27}$ Roudometof, Globalization, 169; see also Victor Roudometof, Alexander Agadjanian, and Jerry Pankhurst, eds., Eastern Orthodoxy in a Global Age: Tradition Faces the Twenty-First Century (Walnut Creek, CA: Alta Mira, 2005).

${ }^{28}$ E.g., Arjun Appadurai, Modernity at Large: Cultural Dimensions of Globalization (Minneapolis: University of Minnesota Press, 1996); Steven Vertovec, Transnationalism (London: Routledge, 2009).

${ }^{29}$ Ulla Vuorela, "Meeting Sophia Mustafa-A Transnational Encounter," in The Tanganyika Way: A Personal Story of Tanganyika's Growth to Independence, ed. Sophia Mustafa (Toronto: TSAR Publication, 2009), 169-80.

${ }^{30}$ See also Helena Kupari, Lifelong Religion as Habitus: Religious Practice among Displaced Karelian Orthodox Women in Finland (Leiden: Brill, 2016), http://booksandjournals.brillonline.com/content/books/9789004326743.

${ }^{31}$ Durre Ahmed, "Women, Psychology, and Religion," in Gendering the Spirit: Women, Religion, and the Postcolonial Response, ed. Durre Ahmed (London: Zed, 2002), 70-87; Kristin Aune et al., "Introduction," Social Compass 64, no. 4, "Thematic Issue: Is Secularism Bad for Women?" (2017): 449-72; Lena Gemzöe and Marja-Liisa Keinänen, "Contemporary Encounters in Gender and Religion: Introduction," in Contemporary Encounters in Gender and Religion: European Perspectives, ed. Lena Gemzöe, Marja-Liisa Keinänen, and Avril Maddrell (Cham: Palgrave Macmillan, 2016), 1-28; Helena Kupari and Elina Vuola, "Introduction," in Orthodox Christianity and Gender: Dynamics of Tradition, Culture, and Lived Practice, ed. Helena Kupari and Elina Vuola (London: Routledge, 2019), 9-13; Mahmood, "Feminist Theory."

${ }^{32}$ For a discussion, see Gemzöe and Keinänen, "Contemporary Encounters."

${ }^{33}$ Nadieszda Kizenko, "Feminized Patriarchy? Orthodoxy and Gender in Post-Soviet Russia," Signs: Journal of Women in Culture and Society 38, no. 3 (2013): 600.

${ }^{34}$ Leonard Norman Primiano, "Vernacular Religion and the Search for Method in Religious Folklife," Western Folklore 54, no. 1 (1995): 43-44; Marion Bowman and Ülo Valk, eds., Vernacular Religion in Everyday Life: Expressions of Belief (Sheffield: Equinox, 2012); Tatiana Tiaynen-Qadir, "Glocal Religion and Feeling at Home: Ethnography of Artistry in Finnish Orthodox Liturgy," Religions 8, no. 2 (2017): 114, https://doi.org/10.3390/rel8020023.

${ }^{35}$ Kupari, Lifelong Religion as Habitus; Sonja Luehrmann, ed., Praying with the Senses: Contemporary Orthodox Christian Spirituality in Practice (Bloomington: Indiana University Press, 2018); David Morgan, Sacred Gaze: Religious Visual Culture in Theory and Practice (Berkeley: University of California Press, 2005); Minna Opas and Anna Haapalainen, eds., Christianity and the Limits of Materiality (London: Bloomsbury, 2017).

${ }^{36}$ Sara Ahmed, "Home and Away: Narratives of Migration and Estrangement," International Journal of Cultural Studies 2, no. 3 (1999): 341. 
${ }^{37}$ Thomas Tweed, Crossing and Dwelling: A Theory of Religion (Cambridge, MA: Harvard University Press, 2006).

${ }^{38}$ John A. McGuckin, "Divine Liturgy, Orthodox," in The Encyclopedia of Eastern Orthodox Christianity, ed. John A. McGuckin (Chichester: Wiley-Blackwell, 2011), 1:190-91.

39 Pavel Florenscy, "Church Ritual as a Synthesis of the Arts," in Beyond Vision: Essays on the Perception of Art, ed. Nicoletta Misler, trans. Wendy Salmond (London: Reaktion, 2002), 109.

40 Tiaynen-Qadir, "Glocal Religion."

${ }^{41}$ Ahmed, "Home and Away," 341.

${ }^{42}$ The names of our interlocutors are pseudonyms. Some details of their narratives have been changed to protect their anonymity.

${ }^{43}$ Molitvoslov pravoslavnoi zhenzhchiny (Moscow: Eksmo, 2008), 13.

${ }^{44}$ For a rich discussion on the role of senses in Orthodox spirituality, see Luehrmann, Praying with the Senses.

${ }^{45}$ Kupari, Lifelong Religion, 59-63.

${ }^{46}$ Huotari, "Orthodox-Lutheran Intermarriage." In fact, the experiences of our older Karelian and younger Finnish interlocutors open up an excellent perspective on some of the effects that this had on the Orthodox community. During the first postwar decades, Orthodox mothers of interconfessional families ended up raising Lutheran children, while Orthodox children mostly had Lutheran mothers. In the interviews, some of our older interlocutors expressed sadness over not having been able to raise their children Orthodox. Kupari, Lifelong Religion, 145-49; see also Marja-Liisa Honkasalo, "If the Mother of God Does Not Listen: Women's Contested Agency and the Lived Meaning of the Orthodox Religion in North Karelia," Journal of American Folklore 128, no. 507 (2015): 65-92. Many of our younger convert interlocutors, for their part, described how Orthodoxy had been present in their childhood through their grandmother or grandfather, while their parents were members of the Lutheran Church.

${ }^{47}$ Kizenko, "Feminized Patriarchy"; Tatiana Tiaynen-Qadir, "Transnational Grandmothers Making Their Multi-sited Homes between Finland and Russian Karelia," in Rethinking Home: Transnational Migration and Older Age, ed. Katie Walsh and Lena Näre (New York: Routledge, 2016), 25-37.

${ }^{48}$ Sarah Riccardi, "Praying through Windows and Peering through Wood: Examining Vernacular Devotions in American Eastern Orthodoxy through a Materialist Lens," master's thesis, Missouri State University, 2014, 34.

${ }^{49}$ See also Luehrmann, Praying with the Senses; Sarah Riccardi-Swartz, "Enshrining Gender: Orthodox Women and Material Culture in the United States," in Orthodox Christianity and Gender: Dynamics of Tradition, Culture, and Lived Practice, ed. Helena Kupari and Elina Vuola (London: Routledge, 2019), 115-30.

${ }^{50}$ See also Kupari, Lifelong Religion, 119-20.

${ }^{51}$ Alexander Schmemann, Celebration of Faith: The Virgin Mary, vol. 3 (New York: St. Vladimir's Seminary Press, 1991). 
${ }^{52}$ Ali Qadir and Tatiana Tiaynen-Qadir, "Deep Culture and the Mystical Agency of Mary in Eastern Christianity," Religions 9, no. 12 (2018): 1-18, https://doi.org/10.3390/rel9120383.

${ }^{53}$ Amy Singleton Adams and Vera Shevzov, eds., Framing Mary: The Mother of God in Modern, Revolutionary, and Postmodern Russia (DeKalb: Northern Illinois University Press, 2018); Jill Dubisch, In a Different Place: Pilgrimage, Gender, and Politics at a Greek Island Shrine (Princeton, NJ: Princeton University Press, 1995); see also Kalkun and Vuola, "The Embodied Mother of God."

${ }^{54}$ S. Alekseev, Chudotvornye ikony Presvyatoi Bogoroditsy (Moscow: Bibliopolis, 2016); I. K. Yazykova, Bogoslovie Ikony (Moscow: Obschedostypnyi Pravoslavnyi Universitet, 1995).

${ }^{55}$ See also Tatiana Tiaynen-Qadir, "Orthodox Icons Generating Transnational Space between Finland and Russia," Lähde-tieteellinen aikakauskirja (2016): 138-71.

${ }^{56}$ The monastery in Heinävesi was established after World War II, to house the evacuated brethren of the monastery in Lake Ladoga. After the fall of the Soviet Union, the latter monastery was reopened.

${ }^{57}$ See also Kalkun and Vuola, "The Embodied Mother of God," 32-4.

${ }^{58}$ See, e.g., Pekka Metso, Nina Maskulin, and Teuvo Laitila, "Tradition, Gender, and Empowerment: The Birth of Theotokos Society in Helsinki, Finland," in Orthodox Christianity and Gender: Dynamics of Tradition, Culture, and Lived Practice, ed. Helena Kupari and Elina Vuola (London: Routledge, 2019), 131-46.

${ }^{59}$ Olavi Merras, “Mikä on Tiistaiseura?” http://www.ortodoksi.net/index.php/Tiistaiseura.

${ }^{60}$ Martikainen and Laitila, "Population Movements," 160-62.

${ }^{61}$ Mircea Eliade, Myth and Reality, trans. Willard R. Trask (New York: Harper \& Row, 1963).

${ }^{62}$ E.g., Helena Jerman, "Memory Crossing Borders: A Transition in Space and Time among Second- and Third-Generation Russians in Finland," in Anthropological Perspectives on Social Memory, ed. Petri Hautaniemi, Helena Jerman, and Sharon Macdonald (Münster: Lit, 2007), 117-41.

${ }^{63}$ Tiina Sotkasiira, "<HS>'Sometimes It Feels Like Every Word Is a Lie': Media Use and Social (In)Security among Finnish Russian-Speakers," Central and Eastern European Migration Review 7, no. 1 (2018): 10927, https://doi.org/10.17467/ceemr.2017.18.

${ }^{64}$ See Tweed, Crossing and Dwelling. 